\title{
Effectiveness of Research-Extension-Farmer linkages of Agricultural Technology Management Agencies in Assam, India
}

\author{
Kamni Paia Biam ${ }^{1 *}$ and Utpal Barman ${ }^{2}$ \\ ${ }^{1}$ Dairy Extension Division, National Dairy Research Institute, Karnal, Haryana, India \\ ${ }^{2}$ Department of Extension Education, Assam Agricultural University, Jorhat, Assam, India \\ *Corresponding author
}

\section{A B S T R A C T}

The purpose of the paper was to compare and assess the effectiveness of ResearchExtension-Farmer linkages of Agricultural Technology Management Agencies (ATMA).

Keywords

ATMA, Assam, Extension reforms, Research-

Extension-Farmers Linkages.

Article Info

Accepted:

15 October 2017

Available Online:

10 December 2017
The study was conducted in Jorhat (World Bank- ATMA) and Golaghat (Central Sector Scheme- ATMA) districts of Assam. The multistage sampling design was followed to collect data from 134 respondents. The linkage effectiveness was studied at the Block level. In the study, Krishi Vigyan Kendra (KVK) was a unit of research; Block Level ATMA was the extension unit and farmers involving with ATMA formed the farmers' unit. A method was developed to obtain linkage effectiveness scores. The study found that the overall linkage effectiveness score between Block Level ATMA- Farmers was highest in both the districts. The Mann-Whitney $U$ test indicated that linkage effectiveness score was higher for ATMA-Golaghat $(M d n=15)$ than for ATMA-Jorhat $(M d n=14),(U=143.1$, $Z=-2.897$ and $p=.486$ ). Kathalguri Block of ATMA Golaghat and Koliapani Block of ATMA-Jorhat scored highest linkage effectiveness score where the KVK of the districts are located on the Block $(U=2.81, Z=-1.202$ and $p=.423)$. The study found that the proximity of Block and KVK and inbuilt mechanism at KVK for ATMA activities increase R-E-F linkage effectiveness.

\section{Introduction}

Research, extension and farmers are the primary components of public extension system, and their effectiveness depends on strong linkage among each other (Sewnet et al., 2016). Havelock (1986) concluded that 'the agricultural research and extension services are the two systems that are linked by information flows, message and response exchanges, and feedbacks and feedforwards'. Linkages establish when two or more subsystem of agriculture extension system establishes communication and working relationship with a commonly shared goal for improving productivity (Agbamu, 2000 and Uzuegbunam and Madukwe, 2005). According to Rathore et al., (2008) linkage mechanism in the extension system refers to the mutual and reciprocal connection between research, extension and farmers. Kyomo (1992) stated that flow of information from agricultural research to farming communities and vice versa requires maintaining a continuous contact by extension workers for making the information understandable to farmers. Agricultural productivity depends on the strength of the link maintained by the 
extension workers with researchers and farmers. Over the years, an enormous amount of research has been done on ResearchExtension-Farmers (R-E-F) linkages of extension system and ample evidence exists to support the view that the linkages of R-E-F are weak in developing countries. Agbamu (2000) argued that research-extensionfarmers linkages in developing countries to be weak and need for reorganisation of the system. Within the area of investigation, some studies reported about the poor R-E-F linkages (Jan and Nawab,2011; Purcell and Anderson, 1997; The World Bank, 1985; and Quimsumbing,1984).

The Policy FrameWork for Agricultural Extension in India noted that the linkages between research-extension and farmer remained weak or non-existent in $\mathrm{T} \& \mathrm{~V}$ system.During the mid-1990s, the Government of India and the World Bank explored new approaches strengthen the extension system in India. (Singh, 2008). Because of that effort, a new institutional innovationemerged termed as Agricultural Technology Management Agency or 'ATMA' model. For implementing the model by all the states, Government of India initiated a new Centrally Sponsored Scheme (CSS) called 'Support to State Extension Programmes for Extension Reforms' on 2005. ATMA is a district level registered society responsible for technology dissemination in the district (Anonymous, nd). It is an institutional innovation, and one of the objectives of ATMA is to strengthen research - extension farmer linkages.

In Assam state, Government adopted the "ATMA model" in 2005.In the last few years, some studies maintained that linkage effectiveness was poor (Kaur and Kaur2013; Rathore et al., 2008, and AFCIL, 2012).However, in thecase of Assam, to date, scant attention has been paid to linkage effectiveness of ATMA model. Therefore the study investigates the effectiveness of R-E-F linkages of ATMA in Assam. The specific objectives of the study were (1) to assess the linkage effectiveness of R-E-F under ATMA at Block level and (2) to compare the linkage effectiveness of R-E-F under two ATMA districts.

\section{Materials and Methods}

The ATMA model implemented in Assam in the first phase was of two types- one is the World Bank funded-ATMA, the other a Centrally Sponsored Scheme (CSS)ATMA.The CSS-ATMA scheme was implemented in 14 districts, and the World Bank covered 12 districts in Assam. One district from each set of ATMA was selected purposively for the study. These were Jorhat district from World Bank funded-ATMA and Golaghat district from CSS-ATMA. The reasons for selection were firstly in both the districts ATMA were covered in the first phase of implementation. Secondly, Krishi Vigyan Kendra (KVK) is located in both the districts. Thirdly, both are from the same agroclimatic zone. The linkage effectiveness of R-E-F under ATMA was assessed at the Block levels purposively as activities for farmers are done mostly at the Block level. There were eight Development Blocks each in Jorhat and Golaghat districts. From each district, three Blocks have been selected randomly. The selected Blocks of Jorhatdistrict was Jorhat Development Block (Baghchung), Koliapani Development Block (Koliapani) and Titabor Development Block (Titabor). The selected Blocks of Golaghat district was Golaghat Central Development Block (Kathalguri), Golaghat West Development Block (Bokakhat) and Golaghat South Development Block (Sarupathar).

The respondents of the study were selected from KVKs, Block Technology Team (BTT) 
members and farmers associated with ATMAs. The head of the KVK designated as Programme Coordinator (PC) in case of CSSATMA is a member of ATMA Governing Body (GB), so he was selected purposively as one respondent from KVK, Golaghat. Each KVK has six Subject Matter Specialist (SMS). In CSS-ATMA, there is one designated KVK scientist who is specifically assigned to carry out ATMA activities as per CSS-ATMA guidelines. Therefore from KVK, Golaghat the designated scientist was also selected as respondent. Two more SMSs were randomly selected from the KVK for the study. Hence from KVK, Golaghat total four respondents were selected for the study. In the World Bank-funded ATMA, there was no provision for a designated scientist, and the PC of the KVK was also not a member of ATMA Governing Body. However, ATMA related activities were done through the $\mathrm{PC}$ of the KVK. So, from KVK, Jorhat the PC was selected as a respondent. All the SMSs were involved in ATMA activities. So, three SMSs were selected randomly from the KVK, Jorhat out of which one was the replacement of the designated scientist. Thus, four KVK scientists were selected from KVK, Jorhat as respondents, making a total of eight $\mathrm{KVK}$ scientists from two districts as respondents under research component of ATMA.

Under ATMA, every Development Block has one Block Technology Team (BTT). It comprises of extension personnel of various disciplines of the concerned Block. For a selection of respondents from each BTT of the selected Development Blocks, first,commondisciplines were identified to which BTT members were assigned to work. One BTT member from each common discipline such as agriculture, veterinary and fishery was selected as respondents. Two Blocks of Jorhat district, where there was no BTT member in sericulture, it was replaced by an additional BTT member. Besides those members, the Block Level ATMA convener was also selected for the survey. Thus, 15 BTT members were selected from each district making the total respondents 30 under extension component of ATMA.

The farmer respondents were selected from the Block Farmer Advisory Committee (BFAC) members, farmers' group and Farmers' Friend. The BFAC comprises of 12 farmers who are the farmers' representatives of various Commodity Interest Groups (CIGs) and Farmers Interest Groups (FIGs). The BFAC members consisted of farmers of different disciplines. First, nine BFAC members from the disciplines were chosen based on numbers of members from each discipline. Thus three agriculture farmers, two horticulture farmers, two fishery farmers and two veterinary farmers were purposively selected from each BFAC of the selected Block.

Secondly, two male and two female respondents from farmers' group members were randomly selected since ATMA is a group approach. Farmers Friend is a new concept introduced in ATMA who is belonged to farmers' community and has the willingness to serve voluntarily for the benefits of farmers under ATMA. Thirdly, three Farmers' Friends from each Block was also selected randomly. Thus 16 farmers were selected from each selected Development Block under ATMA making total 96 farmers as the final respondents from the farmer subsystem. All total, 134 respondents were selected for the study.

In the present study, the linkage effectiveness is operationalised as the score estimated for inter-units linkage based on an assessment of effectiveness by both the actors of a linkage on selected indicators related to the communication and interface activities. In this study the linkages were as follows: 
L1 = Block Level ATMA (E) - KVK (R) linkage

L2 = Block Level ATMA (E) - Farmer $(\mathrm{F})$ linkage

L3 $=$ KVK $(\mathrm{R})-$ Farmer $(\mathrm{F})$ linkage

To explain the variations in the effectiveness of the three linkages across the sampled blocks four dyadic variables were selected which were used as independent variables for relationship analysis.

The selected dyadic variables were (i) The perceived need for interdependence,(ii) Extent of formal and informal contacts,(iii) Initiative for linkage maintenance and (iv) Extent of involvement in each other's' activities. In the present study, the "level of linkage effectiveness" was the dependent variable.

To assess the linkage effectiveness specific indicators based on selected dimensions for each linkage under ATMA were used to calculate the linkage effectiveness status. Scores were assigned to each category of the dimensions, and finally, the overall score was calculated and expressed in percentage using a formula developed for the study.

The linkage effectiveness score for each linkage was calculated by developing the following formula:

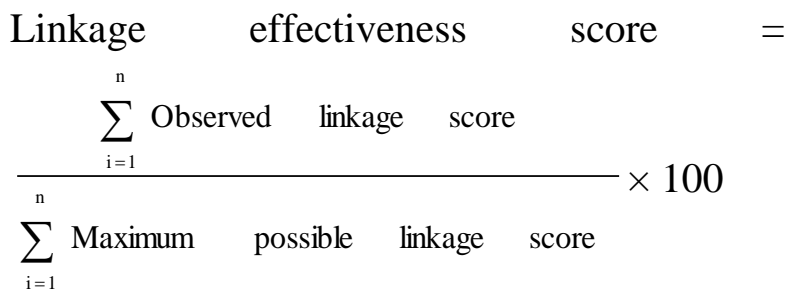

Observed linkage score $(\mathrm{OLS})=($ Sum of total score obtained by all the respondents for that dimension) $\mathrm{X}$ (Number of respondents for each dimension)
Maximum possible linkage score (MPLS) = (Sum of total highest possible score for each dimension) $\mathrm{X}$ (Number of respondents for that dimension). The Mann-Whitney $U$ test was applied to find out the significant differences between the linkages scores of both the districts.

\section{Results and Discussion}

\section{Profile of the respondents}

Table 1 depicts that the average age of participants of BTT members was 47.1 years $(S D=4.70)$. Almost all the BTT members $(96.67 \%)$ were graduates level of education. The average age of the KVK scientists interviewed was 41.3 years $(S D=5.41)$. The educational qualification of all the KVK's respondents was Post Graduates (100.00\%). Table 1 shows the average as of farmers' respondents was 43.7 years $(S D=4.70)$. Majority of the farmers $(67.70 \%)$ had up to high school level of educational qualification.

\section{R-E-F Linkages effectiveness}

The linkage effectiveness score obtained by the different R-E-F linkages under Block level ATMA of Jorhat and Golaghat districts are presented below.

\section{Linkage effectiveness of Block Level ATMA (E) - KVK (R)}

Here total numbers of respondents were 38 $\left(n_{1}=n_{2}=19\right)$. The Table 2 shows that for the linkage between Block Level ATMA and KVK, the linkage effectiveness score in ATMA-Jorhat district was highest in Koliapani Block $(86.13 \%)$. In the case of Golaghat district, it was Kathulguri Block (90.37\%). The KVKs of both the districtsare situated in these Blocks which may facilitate better communication and frequent interaction between KVK and the BTT members. In case 
of other Blocks, it might not be possible due to the distances with the KVK. Lack of official vehicles with BTT members was a problem for interacting with KVK frequently. The KVK had their vehicle, but the single vehicle is not enough for such activities. The study shows that the KVKs which are at the Blocks had better linkages with ATMA. A Mann Whitney $U$ test indicated that linkage effectiveness score for the linkages between Block Level ATMA and KVK in Golaghat was higher than Jorhat. The ' $U$ ' value calculated was significant $(U=128.5, Z=$ 1.536 and $p=.130)$. The reason might bebecause under CSS-ATMA like Golaghat; therewas a provision that the $\mathrm{PC}$ of the KVK is a member of the ATMA -GB. However, in the case of the World Bank-funded ATMAJorhat, no such provisions existed in GB. Under CSS ATMA- Golaghat, there is a designated scientist in the KVK to coordinate ATMA activities. It was absent in case of the World Bank-fundedATMA-Jorhat. The findings thus indicated that presence of designated scientist of KVK for ATMA activities and membership of $\mathrm{PC}$ of $\mathrm{KVK}$ in ATMA GB are two important factors for playing an effective role in strengthening linkages.

The linkage effectiveness scores of the selected Blocks of both the districts were compared with Mann-Whitney $U$ test (Table $3)$. The calculated ' $U$ ' value $(2 *)$ was significant $(Z=-1.091$ and $p=.400)$. The findings maintained that the Block wise linkage effectiveness scores of both the districts for the linkage between Block Level ATMA and KVK are different. The Kathalguri Block under CSS funded ATMAGolaghat ranked first followed by Koliapani Blocks of ATMA -Jorhat. Nearness of the KVKs to theirconcerned Blocks might be a reason for top rankings than the others in both the districts. In all other cases, the ranks of different Blocks of ATMA-Golaghat were found higher than ATMA-Jorhat. The presence of a designated KVK scientist and inclusion of $\mathrm{PC}$ of the $\mathrm{KVK}$ as a member of ATMA GB might help in the effectiveness of linkages. The findings indicated that the linkage effectiveness of Block Level ATMA and KVK varies Block wise in case of Research- Extension linkage.

\section{Linkage effectiveness of Block Level ATMA (E) - Farmer (F)}

It can be observed from Table 4 that the linkage effectiveness score for the linkage between Block Level ATMA and Farmer in ATMA-Jorhat district was highest in Koliapani Block (92.80\%) and with Baghchung and Titabor Blocks having equal linkage effectiveness scores $(90.65 \%)$. In case of Golaghat district, Kathulguri and Bokakhat Blocks had equivalent linkage effectiveness scores $(93.52 \%)$, and Sarupathar Block had 92.80 per cent score. The Mann Whitney $U$ test for the median linkage effectiveness score of ATMA-Jorhat $(M d n=13.5)$ and ATMAGolaghat $(M d n=15)$ was calculated (Table 4). The ' $U$ ' value was found non-significant $(U=1065.5$ and $Z=-2.436, p=0.15)$ for the linkage between Block Level ATMA and farmer for ATMA-Jorhat and ATMAGolaghat. The reason might be that under the CSS-ATMA, and World Bank-funded ATMA provisions for linkage maintenance at the Block level existed where two bodies viz. BTT and BFAC representing extension functionaries and farmers functioned jointly to coordinate ATMA activities and prepared Block Action Plans (BAP) for their respective Blocks. Hence, platforms for the interface between the two actors of the sub-systems were already in place. The findings indicated that cooperation from each BTT and BFAC member in BAP preparation played a vitalrole in strengthening linkages between extension and farmer. 
Table.1 Selected personal characteristics of the respondents

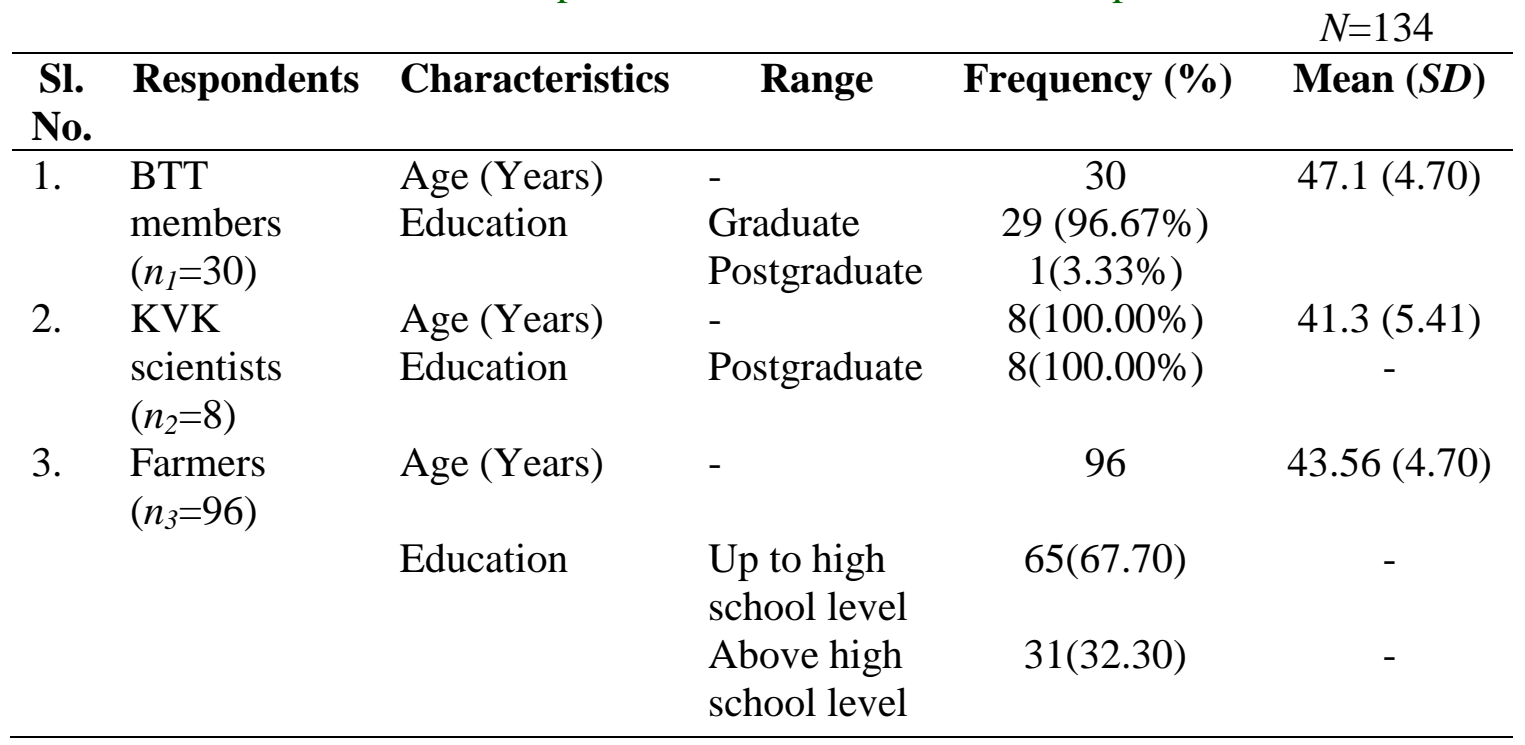

Table.2 Linkage effectiveness score for the selected Blocks of Jorhat and Golaghat districts for the linkage between Block Level ATMA and KVK

\begin{tabular}{|c|c|c|c|c|c|c|}
\hline \multicolumn{3}{|c|}{ ATMA-Jorhat $\left(n_{1}=19\right)$} & \multicolumn{3}{|c|}{ ATMA-Golaghat $\left(n_{2}=19\right)$} & \multirow[b]{2}{*}{$U$} \\
\hline Blocks & $\begin{array}{l}\begin{array}{l}\text { Linkage } \\
\text { effective- }\end{array} \\
\text { ness } \\
\text { score } \\
(\%)\end{array}$ & $\begin{array}{l}\text { Median } \\
\text { linkage } \\
\text { effectiveness } \\
\text { score }\end{array}$ & Blocks & \begin{tabular}{|l|} 
Linkage \\
effective- \\
ness \\
score \\
$(\%)$
\end{tabular} & $\begin{array}{l}\text { Median } \\
\text { linkage } \\
\text { effectiveness } \\
\text { score }\end{array}$ & \\
\hline $\begin{array}{l}\text { Baghchung } \\
\text { Koliapani } \\
\text { Titabor }\end{array}$ & $\begin{array}{l}73.80 \\
86.13 \\
62.06\end{array}$ & 21 & $\begin{array}{l}\text { Sarupathar } \\
\text { Kathalguri } \\
\text { Bokakhat }\end{array}$ & $\begin{array}{l}77.78 \\
90.37 \\
82.22\end{array}$ & 23 & $128.5^{*}$ \\
\hline
\end{tabular}

$\mathrm{Z}=-1.536$ and $*$ Significant at $p=.130$

Table.3 Results of Mann-Whitney $U$ test for comparing the linkage effectiveness scores among all selected Blocks for linkage between Block Level ATMA and KVK

\begin{tabular}{|c|c|c|c|c|c|c|}
\hline \multicolumn{3}{|c|}{ ATMA-Jorhat $\left(n_{1}=3\right)$} & \multicolumn{3}{|c|}{ ATMA-Golaghat $\left(n_{2}=3\right)$} & \multirow[b]{2}{*}{$U$} \\
\hline Blocks & $\begin{array}{c}\text { Linkage } \\
\text { effectiveness } \\
\text { score }(\%)\end{array}$ & Rank & Blocks & $\begin{array}{c}\text { Linkage } \\
\text { effectiveness } \\
\text { score }(\%)\end{array}$ & Rank & \\
\hline Baghchung & 73.80 & 2 & Sarupathat & 77.78 & 3 & \\
\hline Koliapani & 86.13 & 5 & Kathalguri & 90.37 & 6 & $2^{*}$ \\
\hline Titabor & 62.06 & 1 & Bokakhat & 82.22 & 4 & \\
\hline
\end{tabular}

*The difference is significant at $p=.400$ 
Table.4 Linkage effectiveness score for the blocks of Jorhat and Golaghat district for the linkage between Block Level ATMA and farmer

\begin{tabular}{|c|c|c|c|c|c|c|}
\hline \multicolumn{3}{|c|}{ ATMA-Jorhat $\left(n_{1}=54\right)$} & \multicolumn{3}{|c|}{ ATMA-Golaghat $\left(n_{2}=54\right)$} & \multirow[b]{2}{*}{$\boldsymbol{U}$} \\
\hline Blocks & $\begin{array}{l}\text { Linkage } \\
\text { effective- } \\
\text { ness } \\
\text { score }(\%)\end{array}$ & $\begin{array}{l}\text { Median } \\
\text { linkage } \\
\text { effective } \\
\text {-ness } \\
\text { score }\end{array}$ & Blocks & $\begin{array}{l}\text { Linkage } \\
\text { effective- } \\
\text { ness } \\
\text { score }(\%)\end{array}$ & $\begin{array}{l}\text { Median } \\
\text { linkage } \\
\text { effective } \\
\text {-ness score }\end{array}$ & \\
\hline Baghchung & 90.65 & & Sarupathar & 93.52 & & \\
\hline Koliapani & 92.80 & 13.5 & Kathalguri & 93.52 & 15 & 1065.5 \\
\hline Titabor & 90.65 & & Bokakhat & 92.80 & & \\
\hline
\end{tabular}

$\mathrm{Z}=-3.214$ and $*$ Significant at $\mathrm{p}=.012$

Table.5 Results of the Mann-Whitney U test for comparing the linkage effectiveness scores across the Blocks for the linkage between Block Level ATMA and farmer

\begin{tabular}{|c|c|c|c|c|c|c|}
\hline \multicolumn{3}{|c|}{ ATMA-Jorhat $\left(n_{1}=3\right)$} & \multicolumn{3}{|c|}{ ATMA-Golaghat $\quad\left(n_{2}=3\right)$} & \multirow[b]{2}{*}{$\boldsymbol{U}$} \\
\hline Blocks & $\begin{array}{l}\text { Linkage } \\
\text { effectiveness } \\
\text { score }(\%)\end{array}$ & Rank & Blocks & $\begin{array}{l}\text { Linkage } \\
\text { effectiveness } \\
\text { score }(\%)\end{array}$ & Rank & \\
\hline Baghchung & 90.65 & 1.5 & Sarupathar & 93.52 & 5.5 & \multirow{4}{*}{$.500^{*}$} \\
\hline Koliapani & 92.80 & 3.5 & Kathalguri & 93.52 & 5.5 & \\
\hline Titabor & 90.65 & 1.5 & Bokakhat & 92.80 & 3.5 & \\
\hline Sum of rank & & 6.5 & & & 14.5 & \\
\hline
\end{tabular}

*The difference is significant at $p=.100$

Table.6 Linkage effectiveness score for the blocks of Jorhat and Golaghat district for the linkage between KVK and farmer

\begin{tabular}{|c|c|c|c|c|c|c|}
\hline \multicolumn{3}{|c|}{ ATMA-Jorhat $\left(n_{1}=43\right)$} & \multicolumn{3}{|c|}{ ATMA-Golaghat $\left(n_{2}=43\right)$} & \multirow[b]{2}{*}{$\boldsymbol{U}$} \\
\hline Blocks & $\begin{array}{l}\text { Linkage } \\
\text { effective- } \\
\text { ness } \\
\text { score }(\%)\end{array}$ & $\begin{array}{l}\text { Median } \\
\text { linkage } \\
\text { effectiveness } \\
\text { score }\end{array}$ & Blocks & $\begin{array}{l}\text { Linkage } \\
\text { effective- } \\
\text { ness } \\
\text { score }(\%)\end{array}$ & $\begin{array}{l}\text { Medianlin } \\
\text { kage } \\
\text { effective- } \\
\text { ness score }\end{array}$ & \\
\hline $\begin{array}{l}\text { Baghchung } \\
\text { Koliapani } \\
\text { Titabor }\end{array}$ & $\begin{array}{l}58.00 \\
82.50 \\
38.75\end{array}$ & 9 & $\begin{array}{l}\text { Sarupathar } \\
\text { Kathalguri } \\
\text { Bokakhat }\end{array}$ & $\begin{array}{l}66.37 \\
91.48 \\
66.98\end{array}$ & 14 & $132.1^{*}$ \\
\hline
\end{tabular}

$\mathrm{Z}=-3.214$ and $*$ Significant at $\mathrm{p}=.012$ 
Table.7 Results of the Mann-Whitney U test for comparing the linkage effectiveness scores across the Blocks for the linkage between KVK and farmer

\begin{tabular}{|c|c|c|c|c|c|c|}
\hline \multicolumn{3}{|c|}{ ATMA-Jorhat $\left(n_{1}=3\right)$} & \multicolumn{3}{|c|}{ ATMA-Golaghat $\quad\left(n_{2}=3\right)$} & \multirow[b]{2}{*}{$\boldsymbol{U}$} \\
\hline Blocks & $\begin{array}{l}\text { Linkage } \\
\text { effectiveness } \\
\text { score }(\%)\end{array}$ & Rank & Blocks & $\begin{array}{l}\text { Linkage } \\
\text { effectiveness } \\
\text { score }(\%)\end{array}$ & Rank & \\
\hline Baghchung & 58.00 & 2 & Sarupathar & 66.37 & 3 & \\
\hline Koliapani & 82.50 & 5 & Kathalguri & 91.48 & 6 & $2.00^{*}$ \\
\hline Titabor & 38.75 & 1 & Bokakhat & 66.98 & 4 & \\
\hline Sum of ranks & & 8 & & & 13 & \\
\hline
\end{tabular}

$*$ The difference is significant at $p=.400$

Table.8 Overall linkage effectiveness score of Jorhat and Golaghat districts for all the linkage

\begin{tabular}{|c|c|c|c|c|c|c|}
\hline \multicolumn{3}{|c|}{ ATMA-Jorhat $\left(n_{1}=116\right)$} & \multicolumn{3}{|c|}{ ATMA-Golaghat $\left(n_{2}=116\right)$} & \multirow[b]{2}{*}{$\boldsymbol{U}$} \\
\hline Linkages & $\begin{array}{l}\text { Overall } \\
\text { linkage } \\
\text { effective- } \\
\text { ness } \\
\text { score }(\%)\end{array}$ & $\begin{array}{l}\text { Overall } \\
\text { median } \\
\text { linkage } \\
\text { effective- } \\
\text { ness score }\end{array}$ & Linkages & 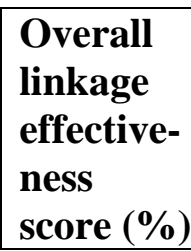 & $\begin{array}{l}\text { Overall } \\
\text { median } \\
\text { linkage } \\
\text { effective- } \\
\text { ness score }\end{array}$ & \\
\hline L1 & 73.99 & \multirow{3}{*}{12} & L1 & 83.46 & \multirow{3}{*}{15} & \multirow{3}{*}{$143.1^{*}$} \\
\hline L2 & 91.36 & & L2 & 93.28 & & \\
\hline L3 & 59.75 & & L3 & 74.94 & & \\
\hline
\end{tabular}

$*$ Significant at $p=.013$

Where

L1 = Block Level ATMA (E) - KVK (R) linkage

L2 $=$ Block Level ATMA (E) - Farmer $(F)$ linkage

$\mathrm{L} 3=\mathrm{KVK}(\mathrm{R})-$ Farmer $(\mathrm{F})$ linkage

Table.9 Results of the Mann-Whitney $U$ test for comparing thelinkage effectiveness scores across the Blocks of both the districts for all the linkage

\begin{tabular}{|c|c|c|c|c|c|c|}
\hline \multicolumn{3}{|c|}{ ATMA-Jorhat $\left(\mathrm{n}_{1}=3\right)$} & \multicolumn{3}{|c|}{ ATMA-Golaghat $\quad\left(\mathbf{n}_{2}=3\right)$} & \multirow[b]{2}{*}{$U$} \\
\hline Linkages & $\begin{array}{c}\text { Linkage } \\
\text { effectiveness } \\
\text { score }(\%)\end{array}$ & Rank & Linkages & $\begin{array}{c}\text { Linkage } \\
\text { effectiveness } \\
\text { score }(\%)\end{array}$ & Rank & \\
\hline L1 & 73.99 & 2 & L1 & 83.46 & 4 & \multirow{4}{*}{$2.82^{*}$} \\
\hline L2 & 91.36 & 5 & L2 & 93.28 & 6 & \\
\hline L3 & 59.75 & 1 & L3 & 74.94 & 3 & \\
\hline Sum of ra & & 8 & & & 13 & \\
\hline
\end{tabular}

Linkage effectiveness scores across the blocks were found to have a significant difference.
The calculated value $(U=.500, Z=-1.826$ and $p=.100$ ) was found significant (Table 5). The 
reason might be due to lack of optimum utilisation of the services of the farmer friend for maintenance of linkage by the Block Level ATMA members.

The farmers particularly in Titabor and Baghchung Blocks of ATMA-Jorhat, indicating that proper utilisation of the farmer friend plays an essential factor in developing linkages between extension functionaries and farmers.Also sometimes shortage of block level and village level staff and manytransfers and changes in extension personnel led to the deterioration of linkages already developed and maintained hampering further communications.

\section{Linkage effectiveness of KVK (R)-Farmer (F) linkage}

The KVK (R) and Farmer (F) linkage are presented in Table 6 . The findings reveals that for the linkage between KVK and farmer the linkage effectiveness score in ATMA-Jorhat district was highest in Koliapani Block $(82.50 \%)$, followed by Baghchung Block $(58.00 \%)$ and Titabor Block $(38.75 \%)$. In case of Golaghat district, Kathulguri Block $(91.48 \%)$ had the highest linkage effectiveness score followed by Bokakhat Block (66.98\%) and Sarupathar Block $(66.37 \%)$. The median linkage effectiveness score of ATMA-Jorhat was 9 and ATMA Golaghat was 4 (Table 6). The ' $U$ ' value calculated was significant $(U=132.1, Z=$ 3.214 and $p=.012$ ) between the linkage effectiveness median score for the linkage between KVK and farmer for ATMA-Jorhat and ATMA-Golaghat. The reason maybe due to the area ofoperation of KVK-Jorhat did not include all the development Blocks of the district as compared to the KVK-Golaghat whose area of activity included all the development Blocks of the district. Lack of awareness among farmers about KVK presence in the district too played an important factor in linkage maintenance between research entities and farmer.

The Mann Whitney $U$ test,it was found that there was a significant difference in the linkage effectiveness scores across Blocks of both Jorhat and Golaghat districts for the linkage between KVK and farmer.The ' $U$ ' value calculated (Table 7) was significant $(U=2.00, Z=-1.091$ and $p=.400)$. The reason might be that proximity of the Blocks viz. Koliapani and Kathalguri towards the KVK have provided better scope for the farmers of the respective Blocks to participate in the KVK activities easily, and the process maintains frequent contacts either formal or informal as compared to other Blocks located at a remote location form the KVK. Also, the variations in the number of activities conducted by the KVKs of the respective districts in the Blocks and lack of transport facilities in remote areas of the district played a major factor in the maintenance of linkages between KVK and farmers.

\section{Overall linkage effectiveness scores of both the districts for all the linkages}

The total linkage effectiveness scores of both the districtsare presented in Table 8. The Table shows that the overall linkage effectiveness score of ATMA-Jorhat for the linkage between Block Level ATMA and Farmer is highest $(91.36 \%)$ in the district and in case of ATMA-Golaghat the linkage between Block Level ATMA and Farmer $(93.28 \%)$ was found to have the highest linkage effectiveness score.

Overall median linkage effectiveness score of ATMA-Golaghat $(M d n=15)$ was higher than ATMA-Jorhat $(M d n=12)$ (Table 8). The ' $U$ ' value calculated was significant $(U=143.11$, $Z=-2.897$ and $p=.013$ ) between the linkage effectiveness median score for all the linkages. The reason might be that under 
CSS-ATMA, there was provision for linkage between Block Level ATMA and KVK at the Block level for preparation of Strategic Research Extension Plan (SREP) for the district which was not the case of World Bank-funded ATMA. There was the absence of a designated KVK scientist in ATMAJorhat, unlike ATMA-Golaghat which had a designated KVK scientist to coordinate their ATMA activities. The additional workload of block ATMA functionaries and role ambiguity might be lead to poor linkage maintenance between KVK personnel in ATMA-Jorhat.Further, the area of operation of the KVK-Jorhat did not include all the Blocks uniformly which was not the case of the KVK-Golaghat whose area of operation includedalmost all the Blocks of the district(Source: Secondary data from Annual Report of respective KVKs). Further, there was lack of optimum utilisation of the Farmer Friend by the Block Level ATMA members and farmers of ATMA-Jorhat to help in the process of linkage as reported by the staffs of ATMA during interviews.

The overall linkage effectiveness scores across the Blocks of both the districts were compared with Mann-Whitney $U$ test (Table 9). The calculated ' $U$ ' value (2.82) was significant $(Z=-1.202$ and $p=.431)$. The findings maintained that the Block wise overall linkage effectiveness scores of both the districts for all three the linkages were different. The linkage L2, i.e. linkage between Block Level ATMA (E) - Farmer (F) under CSS funded ATMA-Golaghat (93.28\%) and World Bank-funded, ATMA-Jorhat (91.36) ranked first and second, respectively. In all other linkages too, it can be observed that variations in overall linkage effectiveness scores exit as substantiated by the calculated $U$ value. The variations may all be attributed to the various reasons stated earlier for each linkage. Hence, it could be inferred that the overall linkage effectiveness for each linkage in the communication triangle varies Block wise for both the districts depending upon various reasons in each case of the R-EFlinkages.

The study showed that the overall linkage between KVK, Block Level ATMA and Farmer in ATMA-Golagh at was more effective than ATMA-Jorhat. It indicated that the ATMA-Golaghat had facilitated the interface between the three actors of the linkage. The study demonstratedthat the absence of a designated KVK scientist to carry out ATMA related work from KVK was a significant factor affecting linkages among the three sub-systems in the researchextension-farmer linkages under the ATMAJorhat. The proximity of KVK to the Block might be another reason for more R-E-F linkages as reflected from the study. Based on the findings the study recommended that there should be an inbuilt platform between Block Level ATMA and KVK like designated KVK scientist for ATMA work. During preparation of annual action plan, the KVKs should keep in mind to uniformly cover all the blocks of a district. Optimum utilisation of the services of the Farmer Friends in the blocks to help link with farmers and conduct regular monitoring of the FIGs and CIGs in their respective blocks. Staffs for ATMAs and KVKs need to be increased along with the provision of the vehicle so that they can maintain the linkages with each stack holders efficiently.

\section{References}

AFCIL, 2012. Evaluation and Impact Assessment of the Centrally Sponsored Scheme "Support to State Extension Programme for Extension Reforms" (ATMA Programme).

Agbamu, J.U., 2000. Agricultural Research, Extension Linkage Systems: An International Perspective, Agricultural Research and Extension Network, 
Department for International Development, U.K., Network Paper No. 106, p.p. 1-7.

Anderson, J, R. and Feder, G. 2004. Agricultural Extension: Good Intentions and Hard Realities, The World Bank Research Observer. 19(1): 41 - 60.

Anonymous, n.d. Agricultural Technology Management Agency. NATP SeriesAgricultural Technology Management Project.

Havelock, R.G., 1986. 'Linkage: a key to understanding the knowledge system' In G.M. Beal, W. Dissanayake and S. Konoshima, (eds) Knowledge Generation, Exchange and Utilisation. Boulder, Colorado: Westview Press. Cited by Agbamu, J. U. Agricultural research-extension linkage systems: an international perspective.

Jan, I., and Nawab, K., 2011. A QuasiLongitudinal Analysis of Agricultural Extension Services in Pakistan. Journal of Extension. 27 (2): 1-11

Kaur, M., and Kaur, R.,2013. Linkage Mechanism of Research-ExtensionFarmer with Market in Punjab. Indian Research Journal of Extension Education. 13(3): 19-24

Kyomo, M.L., 1992. Importance of strong research-extension linkages in increasing livestock production in subSaharan Africa. International Livestock Centre for Africa.

Purcell, D., and Anderson, J. R., 1997. Agricultural extension and research : achievements and problems in national systems. World Development Sources, WDS 1997-2. A World Bank operations evaluation study. Washington, D.C. : The World Bank.

Quimsumbing, E., 1984. New Direction in Research-extension Linkages. In: Elz, D. (ed.) Planning and Management of Agricultural Research, A World Bank and ISNAR Symposium. Washington, D.C.: World Bank. Kassa, B. and Alemu, D (2017). Agricultural Research and Extension Linkages: Challenges and Intervention Options. Ethiop. J. Agric. Sci. 27(1): 55-76.

Rathore, S., Intodia, S. L., and Singh. R. P., 2008. Analysis of Research-ExtensionFarmer Linkage in the Arid Zone of India, Indian Research Journal of Extension Education, 8(2-3): 69-72

Sewnet, Y., Elemo, E., and Derso, D., 2016. A review of agricultural research, extension and farmers linkage in Ethiopia. Agric. Biol. J. N. Am., 7 (3): 116-120.

Uzuegbunam, C. O., and Madukwe, M. C., 2005. Agricultural Research and Extension Network 4(1): 5-9

Singh, K M., 2008. Public-Private Partnerships in Agricultural Extension Management: Experiences of ATMA Model in Bihar and India. http://dx.doi.org/10.2139/ssrn.2254495

World Bank, 1985. Agriculture Research and Extension: An evaluation of the World Bank's experience. Washington, D.C. pp. 110.

\section{How to cite this article:}

Kamni Paia Biam and Utpal Barman. 2017. Effectiveness of Research-Extension-Farmer linkages of Agricultural Technology Management Agencies in Assam, India. Int.J.Curr.Microbiol.App.Sci. 6(12): 1873-1883. doi: https://doi.org/10.20546/ijcmas.2017.612.214 